\title{
Recent glacier variations at the Aconcagua basin, central Chilean Andes
}

\author{
Francisca BOWN, ${ }^{1}$ Andrés RIVERA, ${ }^{1,2}$ César ACUÑ ${ }^{1}$ \\ ${ }^{1}$ Centro de Estudios Científicos, Av. Arturo Prat 514, Casilla 1469, Valdivia, Chile \\ E-mail: fbown@cecs.cl \\ ${ }^{2}$ Departamento de Geografía, Universidad de Chile, Marcoleta 250, Casilla 3387, Santiago, Chile
}

\begin{abstract}
The majority of glaciers in central Chile have receded in recent decades, from $>50 \mathrm{~m}$ to only a few meters per year, mainly in response to an increase in the $0^{\circ} \mathrm{C}$ isotherm altitude. The Aconcagua river basin $\left(33^{\circ} \mathrm{S}\right)$ is one of the major glaciated basins in central Chile, with $121 \mathrm{~km}^{2}$ of ice in 2003. An earlier inventory using 1955 aerial photographs yielded a total surface area of $151 \mathbf{k m}^{2}$, implying a reduction in glacier area of $20 \%\left(0.63 \mathrm{~km}^{2} \mathrm{a}^{-1}\right)$ over the 48 years. Photographic stereo models, high-resolution satellite images (Landsat, ASTER) and SRTM data have been used to delineate glacier basins. A focus on Glaciar Juncal Norte, one of the largest glaciers in the basin, allows a more detailed analysis of changes. The glacier has exhibited a smaller reduction (14\%) between 1955 and 2006, and the resulting elevation changes over this smaller period are not significant. The above reduction rates are lower than in other glaciers of central Chile and Argentina. This trend emphasizes water runoff availability in a river where most of the water in the dry summers is generated by glaciers and snowpack, and where most of the superficial water rights are already allocated. Ongoing hydrological research including modelling of future water runoff will improve our understanding.
\end{abstract}

\section{INTRODUCTION}

The central part of Chile $\left(32-36^{\circ} \mathrm{S}\right)$ is characterized by a Mediterranean climate, with mild wet winters and dry summers. The summers are semi-permanently affected by the blocking of a high-pressure cell over the southeast Pacific Ocean, while during the winter (mainly concentrated between May and September) the westerlies can reach this region and generate frontal and orographic precipitation (Rütllant and Fuenzalida, 1991). The precipitation at high altitudes (above $2500 \mathrm{ma.s.l}$.) fluctuates between $<500 \mathrm{~mm}$ in the northern semi-arid part, to up to $2500 \mathrm{~mm} \mathrm{a}^{-1}$ at $36^{\circ} \mathrm{S}$. The $0^{\circ} \mathrm{C}$ isotherm altitude decreases in the same latitudinal range, from about $4000 \mathrm{ma.s.l}$. at $32^{\circ} \mathrm{S}$ to $<3000 \mathrm{~m}$ a.s.l. at $36^{\circ} \mathrm{S}$ (Carrasco and others, 2005). This allows the presence of an important glacier area in the mountains of this region (Rivera and others, 2000). The variations of the snowline since 1975 showed a midtropospheric warming with an elevation increase of the $0^{\circ} \mathrm{C}$ isotherm of $122 \pm 8 \mathrm{~m}$ in winter, and $200 \pm 6 \mathrm{~m}$ in summer (Carrasco and others, 2005). During the same period, the occurrence of several El Niño-Southern Oscillation (ENSO) events has directly affected water runoff (Waylen and Caviedes, 1990) and the glacier mass balances. This has been systematically observed at Glaciar Echaurren Norte $\left(33^{\circ} 35^{\prime} \mathrm{S}\right)$, where positive mass-balance years are measured during El Niño years, while negative mass balances have been observed during La Niña events (Escobar and others, 1995). As a result of these changes, glaciers have been recognized as key factors contributing to late-summer runoff in many of the main river basins, especially during summers of years with severe drought (like 1968) when up to $67 \%$ of the water flow was generated by glacier meltwater (Peña and Nazarala, 1987). More recent studies have recognized the role of snowmelt as a key factor in explaining runoff variability from this part of the country (Masiokas and others, 2006). Considering the changes in precipitation that have taken place in this region (a general decrease up to
1976, followed by a slight increase afterwards, north of $34^{\circ} \mathrm{S}$ ), the water resources of central Chile have been under pressure during recent decades. This is due to high competition for water allocation as a result of rapid economic growth (Rosegrant and others, 2000). Also, the availability of these resources has been stressed by higher interannual variability of the weather system (mainly associated with ENSO events) and reduction of the glacier areas (Rivera and others, 2006).

Despite being near Santiago, the most populated area of Chile, this glaciological region has been poorly studied. Apart from the pioneering work of Lliboutry (1956), only a few studies have taken place on the Chilean side of the Andes. These include glacier inventories which estimate a total glacier area of $>1000 \mathrm{~km}^{2}$ (Marangunic, 1979; Valdivia, 1984; J. Caviedes, unpublished information; C. Noveroy, unpublished information). These inventories are based upon old aerial photographs and sometimes inaccurate maps. Other glaciological studies carried out in this region include energy-balance (Corripio and Purves, 2005) and ice-thickness (Rivera and others, 2001) measurements, rock glacier studies (Brenning, 2005) and, for the first time in the Chilean Andes, extraction of a $5.5 \mathrm{~m}$ long firn/ice core drilled from the summit (5300 ma.s.l.) of Cerro El Plomo (Bolius and others, 2006).

\section{METHODOLOGY}

\section{Data}

Remotely sensed data used in this study are shown in Table 1, including photogrammetrically derived regular cartography produced by Instituto Geográfico Militar (IGM) based upon the 1955 Hycon aerial survey. The topographic map covers the whole basin area (Fig. 1) at a $1: 50000$ nominal scale and a contour interval of $50 \mathrm{~m}$. In terms of the American Society for Photogrammetry and Remote Sensing, this is Classified I regular cartography, 


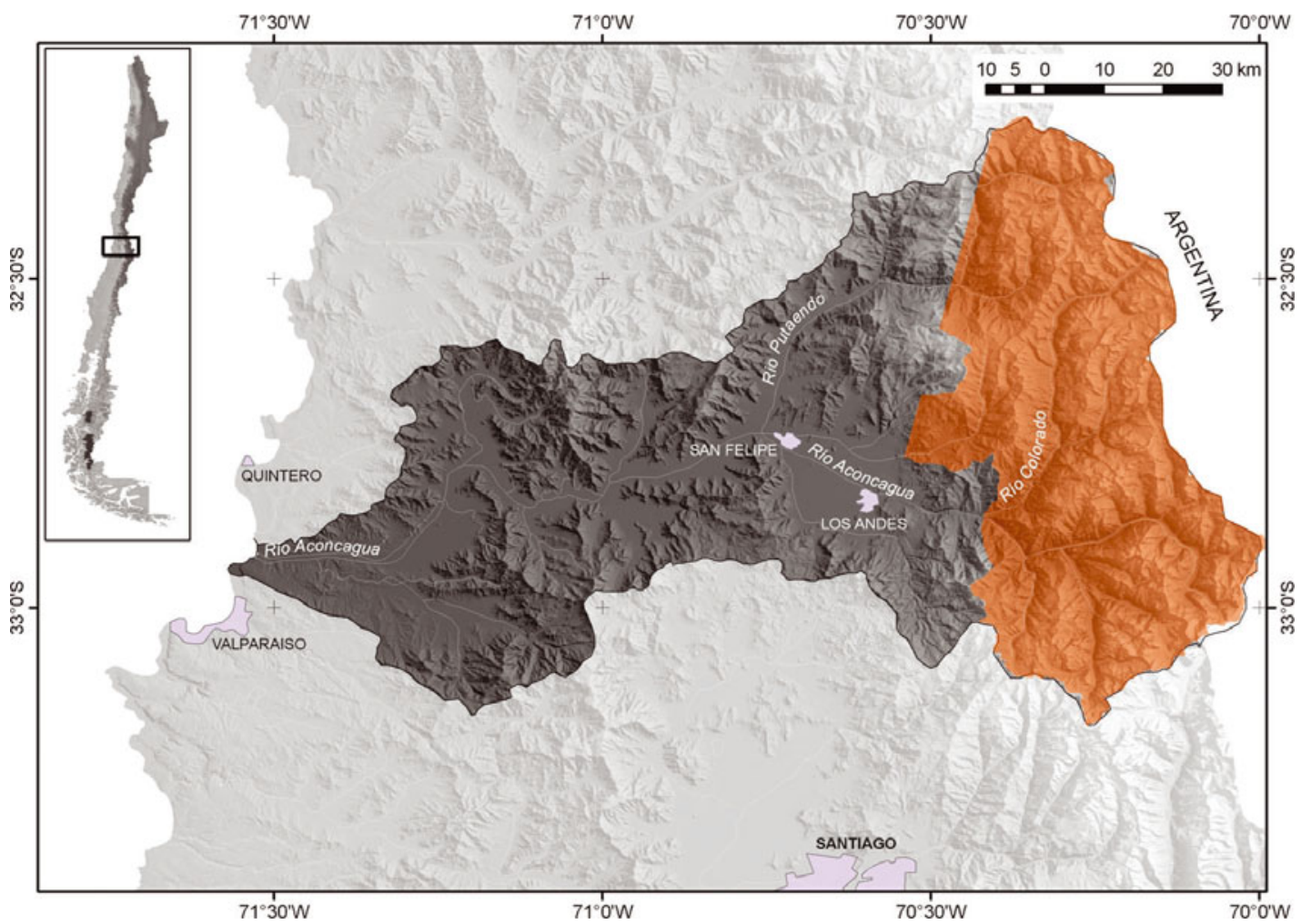

Fig. 1. Location map of the Aconcagua river basin, central Chile, showing river tributaries and most populated cities. The spatial referencing is based on IGM regular cartography. The hill-shade representation of the basin was based on recent and more precise surface topography data (SRTM). Upper glaciated basin is in red.

which has an error estimated at one-third of the contour-line interval according to Falkner (1995), i.e. $17 \mathrm{~m}$. In 1997, Servicio Aerofotogramétrico de Chile updated this former aerial survey at 1:50000 nominal scale based upon the Geotec photographs.

Several high-resolution, cloud-free satellite images have been used for mapping glacier extent in the basin, including Landsat Thematic Mapper (TM) and Enhanced TM Plus $(\mathrm{ETM}+)$, and more recently Advanced Spaceborne Thermal Emission and Reflection Radiometer (ASTER) visible imagery. All images have been georeferenced to the available Instituto Geográfico Militar (IGM) cartography and orthorectified using Shuttle Radar Topography Mission (SRTM) data, following procedures described by, among others, Kääb and others (2003).

Table 1. Remotely sensed data used in this study

\begin{tabular}{lccc}
\hline Sensor/survey & Acquisition date & $\begin{array}{c}\text { Nominal scale/ } \\
\text { spatial resolution }\end{array}$ & Source $^{*}$ \\
\hline Hycon photographs & 1955 & $1: 50000$ & IGM \\
Landsat TM & 17 Mar. 1989 & $28.5 \mathrm{~m}$ & GLCF \\
Geotec & 1997 & $1: 50000$ & SAF \\
Landsat ETM+ & 26 Dec.1999 & $28.5 \mathrm{~m}$ & GLCF \\
SRTM & 10 Feb. 2000 & $90 \mathrm{~m}$ & JPL/NASA \\
ASTER & 24 Mar. 2003 & $15 \mathrm{~m}$ & GLIMS \\
ASTER & 5 Feb. 2006 & $15 \mathrm{~m}$ & GLIMS \\
& & & \\
\hline
\end{tabular}

*IGM: Instituto Geográfico Militar, Chile; GLCF: Global Land Cover Facility; SAF: Servicio Aerofotogramétrico, Chile; JPL: Jet Propulsion Laboratory, California Institute of Technology, Pasadena, CA, USA; GLIMS: Global Land Ice Measurements from Space.

\section{Interpretation of satellite imagery}

Once the satellite images were georeferenced and orthorectified, a classification procedure was applied to account for the glacier extent and snow/ice/debris identification. A histogram analysis of the Landsat TM and ETM+ images was performed, after which segmentation of the ratio of Landsat bands 4 and 5 was used to obtain the best possible glacier classification (Paul and others, 2002). A similar method was applied to ASTER data, using bands $3 \mathrm{~N}$ and 4 . The determination of the variation of glacier fronts was achieved through both stereoscopic analyses of vertical aerial photographs and analyses of satellite imagery. The information obtained from aerial photographs was transferred with a Zoom Transfer Scope (ZTS) to the regular cartography, with ice fronts being digitally compared to the satellite images. All glacier limits were analyzed using commercial Geographical Information System (GIS) software, such as IDRISI 32 for Windows, ArcInfo version 8.0.1 and $\mathrm{PCl}$ Geomatica, which allowed for an accurate estimation of area and frontal changes. An ASTER mosaic was generated from two consecutive scenes acquired on the same date in 2003 (Table 1) which covered the whole basin (Fig. 2). This allowed updating of the complete glacier inventory of the basin.

\section{Analysis of ice elevation data}

1955 IGM topography and 2000 SRTM data have been compared in order to compute the elevation changes at the lower surface of Glaciar Juncal Norte (last 1000 m), which terminates in a long and narrow, partially debris-covered ice tongue. A Boolean mask and $90 \mathrm{~m}$ spatial resolution were selected to account for changes using GIS software. 
Apart from these results, other surface data derive from field campaigns since 1999 as part of a glaciology seminar school at the University of Chile. In February 2003 (midablation season), $\mathrm{H}$. Lange and others (unpublished information) reported the use of geodetic-quality GPS receivers (Trimble Pathfinder) to profile the surface topography of the lower section of the glacier and estimate ice elevation changes. Data acquisition was carried out on a 'stop-and-go' kinematic GPS traverse over the surface, recording several static points and a kinematic route at a constant repetition rate with vertical accuracies on the order of $5 \mathrm{~m}$.

\section{RESULTS}

\section{Glacier inventory}

The calculated glaciated area of Aconcagua for 2003 is $121.2 \mathrm{~km}^{2}$, distributed across a total of 159 glaciers (Table 2). The Andean range reaches elevations higher than $6100 \mathrm{~m}$ a.s.l. at this latitude, with glaciers extending from these highest points down to a minimum of $\sim 3000$ m a.s.l., within five main river sub-basins: Rocín, Colorado, Riecillos, Juncal and Blanco.

The number of glaciers and ice areas per sub-basin have been organized by rank sizes (Table 2) according to the standard classification of the World Glacier Inventory in Zürich, Switzerland (Müller and others, 1977). The smallest rank, between 0.1 and $0.99 \mathrm{~km}^{2}$, is the most frequent.

One of the most important glaciers in this Andean basin is Glaciar Juncal Norte (Fig. 2; $7.6 \mathrm{~km}^{2}$ ), which descends northward from 'Nevado del Juncal'. A number of studies have been carried out there in recent decades, partly thanks to the accessibility of its ablation area and logistics support provided by the Chilean Army. Measurements include recent variations of the glacier (frontal, areal), ice velocities and the surface energy balances (Rivera and others, 2000; Pellicciotti and others, 2007).

Further south is Glaciar del Río Blanco, the only glacier classified in rank 4 . This glacier is in a compound basin formed by several accumulation zones and a common debris-covered ablation area draining to Río Blanco (Fig. 2), and has a total surface area of $24.3 \mathrm{~km}^{2}$. Despite this, there is a noticeable lack of glaciers in rank 4 in the previous inventory by Valdivia (1984), even though this older inventory is reported to be superior in terms of net surface area and number of glaciers. The glaciers forming Glaciar del Río Blanco are mostly smaller than $10 \mathrm{~km}^{2}$, so we hypothesize that they were accounted separately and classified under rank 3 by Valdivia (1984). This could be explained partly by

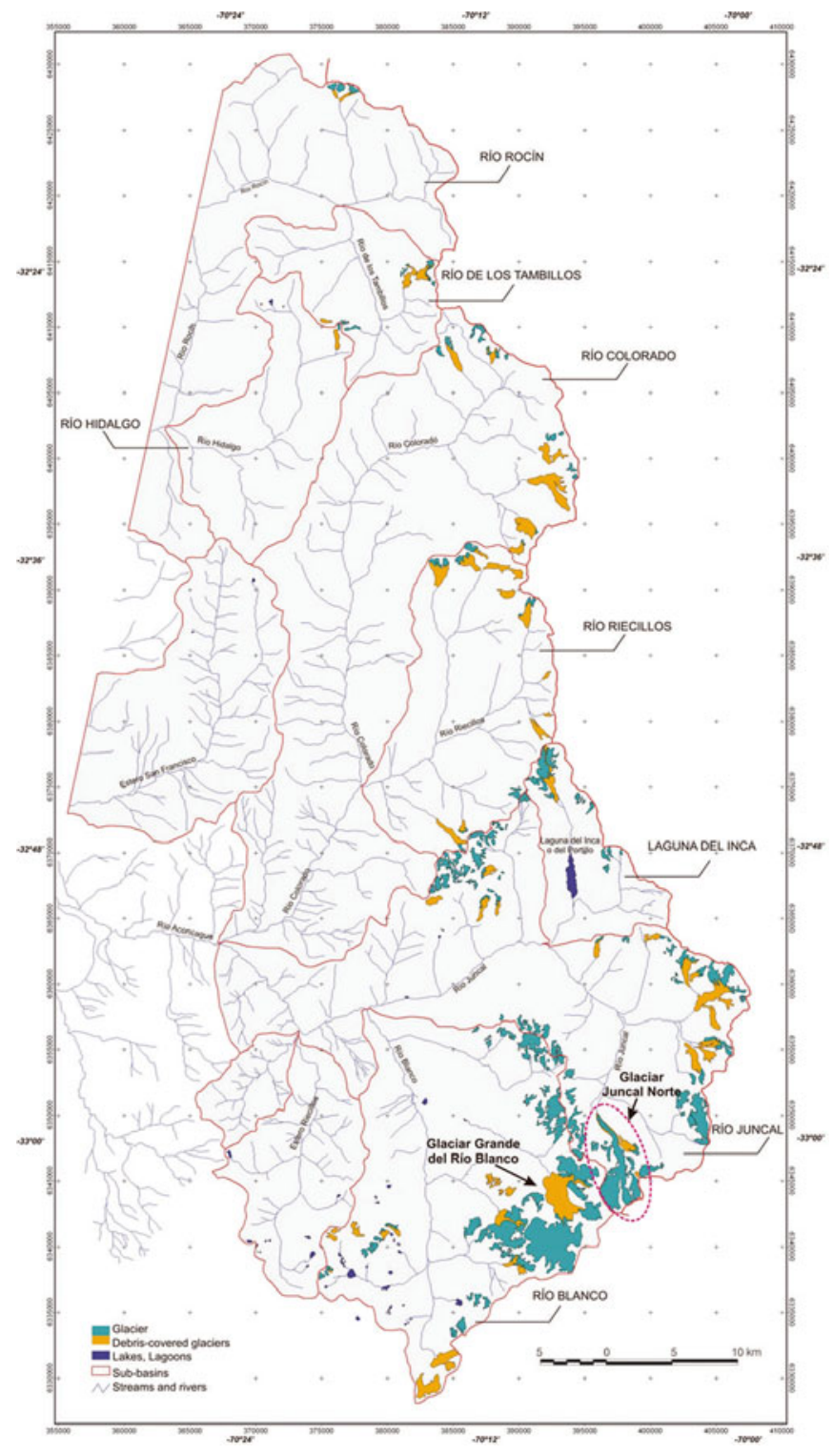

Fig. 2. Ice inventory map for upper Aconcagua basin based on ASTER scenes acquired on 24 March 2003. Sub-basin areas are delineated in red, and river streams in sky-blue. Main glacier areas are located at the Juncal and Río Blanco sub-basins. Glaciar Juncal Norte is circled in red.

stereo matching problems during the photogrammetrical restitution when these glaciers were mapped.

In relation to the aspect of glaciers, they are exposed predominantly to the south-southwestern flank of the valleys

Table 2. Number of glaciers and areas $\left(\mathrm{km}^{2}\right)$ distributed by size rank within the Aconcagua sub-basins

\begin{tabular}{|c|c|c|c|c|c|c|c|c|}
\hline \multirow[t]{2}{*}{ Sub-basin } & \multicolumn{2}{|c|}{ Rank 1 (0.01-0.09) } & \multicolumn{2}{|c|}{ Rank 2 (0.10-0.99) } & \multicolumn{2}{|c|}{ Rank 3 (1.00-9.99) } & \multicolumn{2}{|c|}{ Rank 4 (>10.00) } \\
\hline & Number & Area & Number & Area & Number & Area & Number & Area \\
\hline Río Rocín & - & - & 8 & 3.0 & 1 & 1.1 & - & - \\
\hline Río Colorado & 3 & 0.2 & 7 & 3.5 & 3 & 5.2 & - & - \\
\hline Río Riecillos & - & - & 10 & 4.1 & 4 & 5.4 & - & - \\
\hline Río Juncal & 14 & 0.8 & 49 & 19.6 & 8 & 27.0 & - & - \\
\hline Río Blanco & 7 & 0.4 & 38 & 13.0 & 6 & 13.6 & 1 & 24.3 \\
\hline Total & 24 & 1.4 & 112 & 43.2 & 22 & 52.3 & 1 & 24.3 \\
\hline
\end{tabular}


Table 3. Glacier areas $\left(\mathrm{km}^{2}\right)$ according to types of ice

\begin{tabular}{lcccc}
\hline Sub-basin & $\begin{array}{c}\text { Number of } \\
\text { glaciers }\end{array}$ & Bare-ice area & $\begin{array}{c}\text { Debris- } \\
\text { covered area }\end{array}$ & Total area \\
\hline Río Rocín & 9 & 1.7 & 2.4 & 4.1 \\
Río Colorado & 13 & 3.1 & 5.9 & 9.0 \\
Río Riecillos & 14 & 2.3 & 7.3 & 9.6 \\
Río Juncal & 71 & 35.4 & 12.0 & 47.4 \\
Río Blanco & 52 & 38.5 & 12.8 & 51.3 \\
Total & 159 & 81.0 & 40.4 & 121.2 \\
\hline
\end{tabular}

(nearly $50 \%$ of all inventoried glaciers), so they receive large amounts of oceanic moisture and westerly winds. This is the major source for solid precipitation in the accumulation zones along central Chile (Escobar and Aceituno, 1998). The percentage of glaciers exposed to the south, however, is less in other areas such as the Juncal sub-basin, where there are several larger glaciers ( $40 \%$ of the basin ice surface) with northern aspects and drier conditions prevail. Another spatial feature is the distribution of debris-covered areas along the basin; roughly the northern half is characterized by smaller glaciers which are mostly (in Río Riecillos, 76\% of the total) ice-covered, whereas the southern half consists of more debris-covered glaciers (Table 3 ).

\section{Glacier variations}

By comparing the most recent inventory with the previous study conducted by Valdivia (1984), we find a total glacier area reduction between 1955 and 2003 of $30 \mathrm{~km}^{2}$, equivalent to an annual rate of change of $-0.6 \mathrm{~km}^{2} \mathrm{a}^{-1}$. In absolute terms, this reduction is explained by the decrease of larger surfaces; glaciers ranked 2 (Table 2) have lost $18.3 \mathrm{~km}^{2}$, and when those ranked 3 and 4 are compared to glaciers of rank 3 as provided by Valdivia (1984), they have collectively reduced in area by $9.4 \mathrm{~km}^{2}$. However, the smaller glaciers have been proportionally more affected because they have experienced an area reduction of $>60 \%$, and a reduction in their number from 55 to 24 . This means a disappearance of $66 \%$ of the original smaller glaciers.

Glaciar Juncal Norte is the glacier with the longest documentary record and field data in the Aconcagua river basin, having been first described in 1942 by O. Pfenniger in Lliboutry (1956). Subsequently, several hydroclimate and glaciological studies have been carried out there (Rivera and others, 2000, 2002; Pellicciotti and others, in press). This glacier has suffered a constant retreat at low rates of 4 $23 \mathrm{ma}^{-1}$ (Table 4). The retreat has mainly affected the partially debris-covered front and surroundings of the $2 \mathrm{~km}$ long, $500 \mathrm{~m}$ wide and $186 \mathrm{~m}$ thick lower tongue of the glacier (Rivera and others, 2001). The total glacier area loss between 1955 and 2006 is $1.5 \mathrm{~km}^{2}$ (Table 4). This is much more than the previous estimation by Rivera and others (2002). One explanation could be that the latest calculation considers the changes taking place all around the glacier, i.e. it includes the upper accumulation area where the glacier is also shrinking (Fig. 3). Frontal variations in recent decades are small in comparison with other retreating glaciers in northern and central Chile (e.g. the observed changes at Glaciar Juncal Sur, with frontal retreats higher than $50 \mathrm{~m} \mathrm{a}^{-1}$ in a similar period of time (Rivera and others, $2000,2002))$. This smaller retreat rate could also be related
Table 4. Frontal and areal changes at Glaciar Juncal Norte

\begin{tabular}{lccc}
\hline Period & Frontal change & $\begin{array}{c}\text { Frontal change rate } \\
\mathrm{m} \mathrm{a}^{-1}\end{array}$ & $\begin{array}{c}\text { Area change } \\
\mathrm{km}^{2}\end{array}$ \\
& & & \\
\hline $1955-89$ & -120 & -4 & -0.08 \\
$1989-97$ & -185 & -23 & -1.00 \\
$1997-99$ & -40 & -20 & -0.03 \\
$1999-2006$ & -119 & -17 & -0.35 \\
$1955-2006$ & -464 & -9.1 & -1.46 \\
\hline
\end{tabular}

to topographic constraints at Juncal Norte, where the position of the glacier snout at the bottom of a deep valley surrounded by high mountains is continuously shadowing the ice.

Ice-elevation changes at the lower part of the glacier were computed by subtraction between SRTM 2000 and the IGM cartographically derived digital elevation model (1955). The signal remains well below the noise ratio, which comprises the combined root mean square (rms) of the IGM map (17 m) and the SRTM data $(12 \mathrm{~m})$. Therefore, no significant trend can be detected by comparing the two datasets. However, the GPS profile reported in $\mathrm{H}$. Lange and others (unpublished information), i.e. the ice surface between 2925 and $3096 \mathrm{~m}$ a.s.l. (1000 $\mathrm{m}$ long traverse), as compared to IGM cartography, accounted for an annual thinning rate of $0.58 \pm$ $0.37 \mathrm{~m} \mathrm{a}^{-1}$ during the 48 year period. At higher altitudes, there are GPS data accounting for further negative elevation changes; nevertheless they remain well below the rms error (H. Lange and others, unpublished information).

\section{DISCUSSION}

Aconcagua is one of the main glaciated basins in central Chile (Rivera and others, 2000). Other important glaciated basins in this region are Maipo $\left(33^{\circ} \mathrm{S}\right)$, Cachapoal $\left(34^{\circ} \mathrm{S}\right)$ and Tinguririca $\left(35^{\circ} \mathrm{S}\right)$, although no updating of the old ice inventories has been carried out yet for the rivers south of Aconcagua. Taking into account the information available to date, this basin represents $14 \%$ of the total ice area between $32^{\circ}$ and $35^{\circ} \mathrm{S}$. If the $20 \%$ area loss experienced by the Aconcagua river during the past five decades (1955-2006) is applied over a similar period of time to the other basins of central Chile, the regional total loss may be $>200 \mathrm{~km}^{2}$ of ice. Within Chile, this large retreat is only comparable to what has been experienced by the icefields south of $53^{\circ} \mathrm{S}$ (Porter and Santana, 2003; Möller and others, 2007; Schneider and others, 2007), or in other parts of South America, by Andean tropical glaciers (Pouyaud and others, 2005). Even in Patagonia, the changes are proportionally much smaller, with area reductions of $3-4 \%$ in Hielo Patagónico Norte and Sur (northern and southern Patagonia icefields) respectively (Aniya and others, 1996; Rivera and others, 2007).

The glaciers in the Aconcagua basin seem to be responding to climate change detected in the meteorological network (Rosenblüth and others, 1997; Quintana, 2004). The most likely driving factor is the tropospheric warming observed in radiosonde records, especially between 850 and $500 \mathrm{hPa}$ (Carrasco and others, 2005). This may explain the glacier frontal retreats, ice surface reduction and thinning (Rivera and others, 2002), since the amount of 


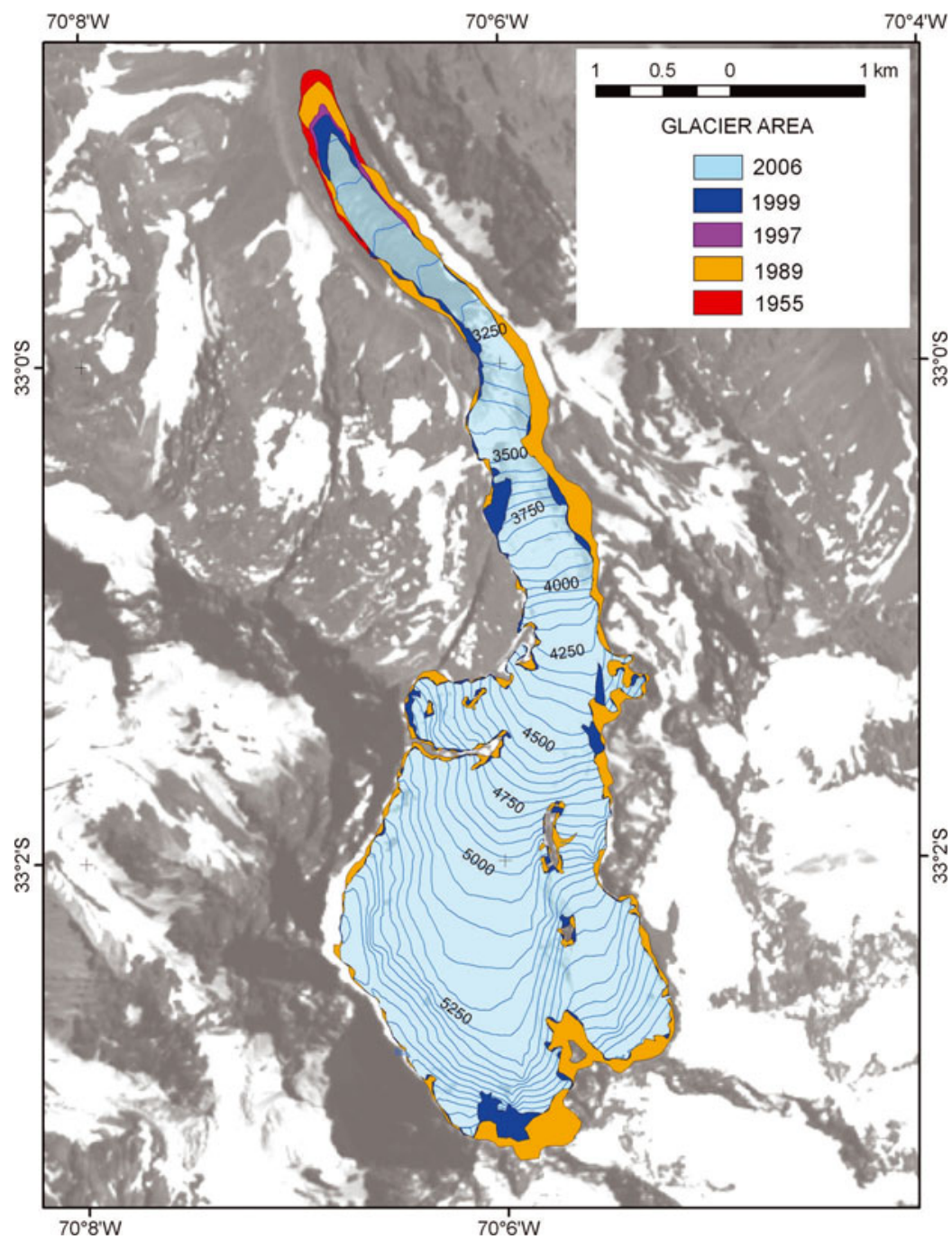

Fig. 3. Glaciar Juncal Norte areal variations from 1955. Contour lines (in m) are based upon SRTM data.

precipitation (in the form of snow reaching the surface), or ice melting in the ablation areas, is affected by atmospheric changes. In addition, the occurrence of ENSO phenomena plays an important role in controlling snowfall at this latitude - including consequences for runoff trends - with some negative implications for glaciers in the most extreme La Niña years and clear and significant positive effects during almost all recent El Niño years (Escobar and others, 1995; Rivera and others, 2000; Masiokas and others, 2006).

Factors other than climate, such as complex valley geometry, aspect or debris cover, may disrupt linear glacier responses to increasing temperature or decreasing precipitation. Whereas debris cover has not prevented the disappearance of smaller glaciers, in other cases local characteristics may have attenuated the glaciological effects of ongoing climate change. Juncal Norte is a good example of these local factors.

\section{CONCLUSIONS}

Glacier changes in central Chile may have a strong impact on present and future water resources due to the increasing competition among users as a result of the economic growth experienced by the country in recent decades (Rosegrant and others, 2000). The glacier contribution has been recognized to be crucial, particularly in periods of drought or very dry summers, when it has been observed that up to $67 \%$ of the total runoff may originate from the melting of glaciers (Peña and Nazarala, 1987).

The Aconcagua river constitutes an important glaciated basin in the boundary zone between semi-arid and temperate conditions. It supports many economic activities and a large part of the national population. Glaciers in this basin have been shown to be responding to climate change, and in particular to the elevation of the zero degree isotherm (Carrasco and others, 2005), with area losses, frontal retreats and surface ice thinning. Specific glacier responses may be explained by local factors, but they also suggest the use of more accurate methods other than remote sensing in order to detect glacier variations. Geophysical field surveys and/or aircraft-borne measurements are required. The trend to decreasing runoff observed in the Aconcagua river (Pellicciotti and others, in press) can largely be explained by a reduced contribution of glaciers and snow.

The current trend to reduced runoff will continue in the future if the climatic warming patterns continue, and overall glacier mass will be further reduced. Many small glaciers will probably disappear, contributing less water to the rivers. In the tropical Andes, for example, small glaciers are already disappearing (Coudrain and others, 2005) and hydrological models are forecasting a significant decay in water storages over the next few decades (Pouyaud and others, 2005). 
Further knowledge and research will be necessary to improve insights into future glacier trends in this region and implications for water resource availability.

\section{ACKNOWLEDGEMENTS}

This work is sponsored by Centro de Estudios Científicos, Chile (CECS). CECS is funded by a grant from the Millennium Science Initiative and the Regional Center on Innovative Technology, among others. We thank the Comision Nacional de Investigacion Cientifica y Technologica de Chile (CONICYT) for travel assistance under grant ACl-04. This research used satellite images provided by the Global Land Ice Measurements from Space (GLIMS) project and the Global Land Cover Facility at the University of Maryland, USA. We thank L. Copland for revising our English.

\section{REFERENCES}

Aniya, M., H. Sato, R. Naruse, P. Skvarca and G. Casassa. 1996. The use of satellite and airborne imagery to inventory outlet glaciers of the Southern Patagonia Icefield, South America. Photogramm. Eng. Remote Sens., 62(12), 1361-1369.

Bolius, D., M. Schwikowski, T. Jenk, H.W. Gäggeler, G. Casassa and A. Rivera. 2006. A first shallow firn-core record from Glaciar La Ollada, Cerro Mercedario, Central Argentine Andes. Ann. Glaciol., 43, 14-22.

Brenning, A. 2005. Geomorphological, hydrological and climatic significance of rock glaciers in the Andes of Central Chile (33$35^{\circ}$ S). Permafrost Periglac. Process., 16(3), 231-240.

Carrasco, J.F., G. Casassa and J. Quintana. 2005. Changes of the $0^{\circ} \mathrm{C}$ isotherm and the equilibrium line altitude in central Chile during the last quarter of the 20th century. Hydrol. Sci. J., 50(6), 933-948.

Corripio, J. and R. Purves. 2005. Surface energy balance of high altitude glaciers in the central Andes: the effect of snow penitents. In De Jong, C., D.N. Collins and R. Ranzi, eds. Climate and hydrology of mountain areas. Chichester, J. Wiley and Sons, 15-27.

Coudrain, A., B. Francou and Z.W. Kundzewicz. 2005. Glacier shrinkage in the Andes and consequences for water resources: editorial. Hydrol. Sci. J., 50(6), 925-932.

Escobar, F., G. Casassa and V. Pozo. 1995. Variaciones de un glaciar de Montaña en los Andes de Chile Central en las últimas dos décadas. Bull. Inst. Fr. Étud. Andin. [Lima], 24(3), 683-695.

Escobar, F. and P. Aceituno. 1998. Influencia del fenómeno ENSO sobre la precipitación nival en el sector andino de Chile Central durante el invierno austral. Bull. Inst. Fr. Étud. Andin. [Lima], 27(3), 753-759.

Falkner, E. 1995. Aerial mapping: methods and applications. Boca Raton, FL, Lewis Publishers.

Kääb, A. and 6 others. 2003. Glacier monitoring from ASTER imagery: accuracy and application. EARSeL eProc., 2(1), 43-53.

Lliboutry, L. 1956. Nieves y glaciares de Chile: fundamentos de glaciología. Santiago, Ediciones de la Universidad de Chile.

Marangunic, D.C. 1979. Inventario de glaciares en la hoya del Río Maipo. Santiago, Ministerio de Obras Públicas. Dirección General de Aguas.

Masiokas, M., R. Villalba, B.H. Luckman, C. Le Quesne and J.C. Aravena. 2006. Snowpack variations in the central Andes of Argentina and Chile, 1951-2005: large-scale atmospheric influences and implications for water resources in the region. J. Climate, 19(24), 6334-6352.
Möller, M., C. Schneider and R. Kilian. 2007. Glacier change and climate forcing in recent decades at Gran Campo Nevado, southernmost Patagonia. Ann. Glaciol., 46, 136-144.

Müller, F., T. Caflisch and G. Müller. 1977. Instructions for the compilation and assemblage of data for a world glacier inventory. Zürich, ETH Zürich. Temporary Technical Secretariat for the World Glacier Inventory.

Paul, F., A. Kääb, M. Maisch, T. Kellenberger and W. Haeberli. 2002. The new remote-sensing-derived Swiss glacier inventory. I. Methods. Ann. Glaciol., 34, 355-361.

Pellicciotti, F., P. Burlando and K. van Vliet. 2007. Recent trends in precipitation and streamflow in the Aconcagua river basin, central Chile. IAHS Publ. 318 (Assembly at Foz do Iguaçu 2005 - Glacier Mass Balance Changes and Meltwater Discharge).

Peña, H. and B. Nazarala. 1987. Snowmelt-runoff simulation model of a central Chile Andean basin with relevant orographic effects. IAHS Publ. 166 (Symposium at Vancouver 1987 - Large Scale Effects of Seasonal Snow Cover), 161-172.

Porter, S.C. and A. Santana. 2003. Rapid 20th century retreat of Ventisquero Marinelli in the Cordillera Darwin Icefield. An. Inst. Patagonia, 31, 17-26.

Pouyaud, B. and 6 others. 2005. Avenir des ressources en eau glaciaire de la Cordillère Blanche. Hydrol. Sci. J., 50(6), 999-1022.

Quintana, J. 2004. Estudio de los factores que explican la variabilidad de la precipitación en Chile en escalas de tiempo interdecadal. (MSc thesis, Universidad de Chile.)

Rivera, A., G. Casassa, C. Acuña and H. Lange. 2000. Variaciones recientes de glaciares en Chile. Rev. Invest. Geogr., 34, 29-60.

Rivera, A., G. Casassa and C. Acuña. 2001. Mediciones de espesor en glaciares de Chile centro-Sur. Rev. Invest. Geogr., 35, 67-100.

Rivera, A., C. Acuña, G. Casassa and F. Bown. 2002. Use of remotely sensed and field data to estimate the contribution of Chilean glaciers to eustatic sea-level rise. Ann. Glaciol., 34, 367-372.

Rivera, A., C. Acuña and G. Casassa. 2006. Glacier variations in central Chile $\left(32^{\circ} \mathrm{S}-41^{\circ} \mathrm{S}\right)$. In Knight, P.G., ed. Glacier science and environmental change. Oxford, etc., Blackwell Science, 246-247.

Rivera, A., T. Benham, G. Casassa, J. Bamber and J.A. Dowdeswell. 2007. Ice elevation and areal changes of glaciers from the Northern Patagonia Icefield, Chile. Global Planet. Change, 59(1-4), 126-137.

Rosegrant, M.W., C. Ringler, D.C. McKinney, X. Cai, A. Keller and G. Donoso. 2000. Integrated economic-hydrologic water modeling at the basin scale: the Maipo river basin. Agric. Econ., 24(1), 33-46.

Rosenblüth, B., H.A. Fuenzalida and P. Aceituno. 1997. Recent temperature variations in southern South America. Int. J. Climatol., 17(1), 67-85.

Rütllant, J. and H. Fuenzalida. 1991. Synoptic aspects of the central Chile rainfall variability associated with the Southern Oscillation. Int. J. Climatol., 11(1), 63-76.

Schneider, C., M. Schnirch, C. Acuña, G. Casassa and R. Kilian. 2007. Glacier inventory of the Gran Campo Nevado Ice Cap in the Southern Andes and glacier changes observed during recent decades. Global Planet. Change, 59(1-4), 87-100.

Valdivia, P. 1984. Inventario de glaciares Andes de Chile central $\left(32^{\circ}-35^{\circ}\right.$ lat. S). Hoyas de los ríos Aconcagua, Maipo, Cachapoal y Tinguiririca. In Jornadas de Hidrología de Nieves y Hielos en América del Sur, Santiago, Chile, 3 al 8 de Diciembre 1984. Santiago, UNESCO. Programa Hidrólogico Internacional, 6.1-6.24.

Waylen, P.R. and C.N. Caviedes. 1990. Annual and seasonal fluctuations of precipitation and streamflow in the Aconcagua River basin, Chile. J. Hydrol., 120(1-4), 79-102. 